\title{
Morphometric abnormalities in the spleen of the progeny of mice fed epigallocatechin during gestation and nursing
}

\author{
B.J. Bałan1, E. Skopińska-Różewska ${ }^{2,3}$, P. Skopiński ${ }^{4}$, R. Zdanowski², \\ M. Leśniak ${ }^{2}$, A. Kiepura ${ }^{2}$, S. Lewicki ${ }^{2}$ \\ ${ }^{1}$ Department of Immunology, Biochemistry and Nutrition, Warsaw Medical University, \\ Oczki 3, 02-004, Warsaw, Poland \\ ${ }^{2}$ Department of Regenerative Medicine and Cell Biology, Military Institute of Hygiene and Epidemiology, \\ Kozielska 4, 01-163, Warsaw, Poland \\ ${ }^{3}$ Department of Pathomorphology \\ ${ }^{4}$ Department of Histology and Embryology, Center for Biostructure Research, Warsaw Medical University, \\ Chałubińskiego 5, 02-004, Warsaw, Poland
}

\begin{abstract}
It is very difficult to cure pregnant females suffering from infections, because of the risk which might occur during treatment by several, even herbal, medications. Many of these substances, among them extracts from plants, have antimicrobial, anti-inflammatory and immunostimulatory properties owing to their polyphenols content, but also may reveal unwanted effects on the fetal development because of their anti-angiogenic properties. The aim of the present study was to elucidate whether daily feeding pregnant and nursing mice $0.2 \mathrm{mg} / \mathrm{kg}$ epigallocatechin (EGC), previously recognized as angiogenesis inhibitor, may lead to abnormalities in morphology of spleen and in some parameters of immune function of their adult, 6-week old progeny. Morphometry of EGC offspring spleens revealed lower number of lymphatic nodules and their larger diameter than those found in the control offspring. Cellularity of spleens was lower in EGC offspring than in the controls. Cytometric analysis showed that this decline concerns lymphocytes with CD335 ( $\mathrm{p}<0.001)$, CD19 $(\mathrm{p}<0.01)$ and CD4 $(\mathrm{p}<0.05)$ markers. No differences were observed in the humoral response to the immunization with SRBC, and in the proliferative response of splenocytes to mitogens PHA, ConA and LPS.
\end{abstract}

Key words: mice, pregnancy, epigallocatechin, progeny spleen, morphometry, immune response 


\section{Introduction}

Angiogenesis is an important component of many physiological phenomena, and with vasculogenesis, it is the engine of the development of tissues and organs in the embryonic and fetal life. Products commonly used in human and animal nutrition contain many substances that could potentially affect the process of angiogenesis. Among these, polyphenols occupy a significant position. Polyphenols are characterized by high diversity of structure. This diversity is responsible for differences in their bioavailability and biologic properties. In the study of Grosso et al (2014), performed in Polish soldiers, the highest daily polyphenols intakes were found for flavonoids (mainly flavanols) and phenolic acids (mainly hydroxycinnamic acids). According to these authors, the highest intakes were found mainly for isomers of chlorogenic acid (average intake $705 \mathrm{mg} / \mathrm{d}$ ) and flavanols belonging mainly to the catechin group (average intake 637 $\mathrm{mg} / \mathrm{d})$.

There is a lot of studies regarding the impact of these substances, present in herbal products and food supplements, on tumors vascularization and angiogenic activity of their cells (Fotsis et al. 1997, Bałan et al. 1999, Cao et al. 2002, Kandaswami et al. 2005, Kim et al. 2012, Zdanowski et al. 2012, Skopiński et al. 2013, Shi et al. 2015).

However, the information on the influence of antiangiogenic polyphenolic compounds on fetal development and, subsequently, on the health of adult progeny, is scanty. On the model of the pregnant mice it has been shown that some drugs, foods, herbal extracts and their compounds, administered during pregnancy and nursing, may cause adverse effects on the immune system of adult offspring (Skopińska-Różewska et al. 1985, 2004a,b, Chorostowska-Wynimko et al. 2004, Lewicki et al. 2016, Bałan et al. 2017).

It was also demonstrated that the main cocoa catechins affect embryonic angiogenesis (Skopinski et al. 2004, Wasiutynski et al. 2005). Catechin-rich food and diet supplements (chocolate, cranberry and Rhodiola extracts), added to the daily diet of pregnant and nursing mice, caused in the offspring disorders of bone mineralization and renal glomeruli development (Skopiński et al. 2003, Patera et al. 2006, Bałan et al. 2017, Lewicki et al. 2017).

The spleen is the largest secondary lymphoid organ containing about one-fourth of the body's lymphocytes. There are two morphologically distinct compartments in the mouse spleen, the red pulp and the white pulp, which are the site of hematopoiesis, particularly in fetal and neonatal animals. The white pulp surrounds the central arterioles and is composed of three sub-compartments: the peri-arteriolar lymphoid sheath (PALS), the follicles with germinal centers composed primarily of $\mathrm{B}$ cells, and the marginal zone. PALS is a T-cell dependent region, containing CD4 and CD8 T-cells, and smaller amount of CD19 B-cells and dendritic cells. The outer PALS and marginal zone contain both B- and T-cells and macrophages. Natural killer (NKp46/CD335 ${ }^{+}$) cells were mostly localized in the splenic red pulp (Walzer et al. 2007). An important function of the spleen is the initiation of the immune response to blood-borne antigens (Cesta 2006).

The aim of the present study was to investigate the effect of epigallocatechin, a flavonoid with anti-angiogenic properties, on the morphology of spleen, spleen lymphocytes phenotypes, splenocytes response to mitogens, and anti-SRBC antibody production in the offspring of mice that were fed this compound during pregnancy and nursing.

\section{Materials and Methods}

Epigallocatechin (EGC) was purchased from Sigma Aldrich (cat. No. E3768-5MG), dissolved in distilled water and stored at $-70^{\circ} \mathrm{C}$ until used.

\section{Animals}

Experiments were performed on adult inbred females of Balb/c strain, 8-9 weeks old, mated with adult males from the same strain, and on their 6-weeks old offspring. The animals were handled according to the Polish law on the protection of animals and NIH standards. All experiments were accepted and conducted according to the ethical guidance of the Local Bioethical Committee (permission 73/2011). Mice, from the time when copulatory plug was noted up to the 28-th day after delivery, were fed EGC $(0.2 \mathrm{mg} / \mathrm{kg}$ b.m.) daily. Mothers were housed separately. For avoiding stress connected with gavage and handling, 20 microliters of EGC water solution was placed on a corn crisp and served to the mouse in a Petri dish. The control group received corn crisp with 20 microliters of distilled water, as placebo. The mice were maintained under typical conditions (temperature $22.5-23.0^{\circ} \mathrm{C}$, relative humidity $50-70 \%, 12 \mathrm{~h}$ day/night cycle) with ad libitum access to breeding rodent feed (Labofeed H, Factory of Fodder Morawski, Kcynia, Poland) and water. The female and male progeny were housed separately. The pups were withdrawn from mothers 24 days following delivery. Six weeks after birth, part of the progeny of control mothers and EGC mothers were weighed, anesthetized, bled and euthanized. Spleens were dissected aseptically and 
part of them were fixed in buffered formalin and processed for histological examination.

The rest of the spleens served for the evaluation of cellularity, leukocytes subpopulations and their CD markers, and proliferative response to mitogens.

Remaining progeny of control and EGC mothers were immunized with sheep red blood cells (SRBC) for evaluation of antibody production.

\section{Spleen isolation}

The mice were bled from retro-orbital plexus under anesthesia [intraperitoneal injection of ketamine $(120 \mathrm{mg} / \mathrm{kg})$ and xylazine $(12 \mathrm{mg} / \mathrm{kg})$; Polypharm S.A., Warsaw, Poland]. Following bleeding, the mice were sacrificed by anesthetic overdose (pentobarbital, 400 $\mathrm{mg} / \mathrm{kg}$; Polypharm S.A) and spleens were isolated under aseptic conditions.

\section{Morphometric evaluation of spleens}

Histological evaluation and quantitative analyses of lymphatic nodules were performed on hematoxylin and eosin stained paraffin sections of the spleens obtained from the progeny (10 spleens from each group). The histotechnical criteria applied for quantitative analysis were as follows: i) A thickness of between 3 and $5 \mu \mathrm{m}$; ii) complete transversal section of the spleen including white and red pulp structures; and (iii) no evidence of traumatic artifacts within the sample, such as fragmentation or hemorrhage.

Light microscopy examination using an Evolution 100 Trino optical microscope (Delta Optical; Minsk Mazowiecki, Poland) connected to a photometric color CCD camera (UCMOS05100KPA; Hangzhou ToupTek Photonics Co., Ltd., Hangzhou, China) was based upon the standard morphological criteria. Fixed spleen preparations were examined using a panchromatic lens, numerical aperture 0.25 using magnification of $\mathrm{x} 10$. Spectacle had $\mathrm{x} 10$ magnification, total magnification was $\mathrm{x} 100$.

\section{Quantitative analysis of lymphatic nodules}

The surface of the section of spleen was analyzed in regards to the following: i) the total area and number of white pulp lymphatic nodules, with the results expressed as the number per microscopic field (5.5 $\mathrm{mm}^{2}$ ); and ii) lymphatic nodule diameters measured in consecutive nodules of examined sample. Images were acquired and processed using ToupView software (version 3.7; ToupTek Photonics Co., Ltd.).

\section{Preparation of splenocyte suspension}

Spleens were gently pressed through a sterile nylon strainer $(40 \mu \mathrm{m})$ into a $50 \mathrm{ml}$ Flacon tube with 20 $\mathrm{ml}$ of culture medium (Roswell Park Memorial Institute no 1640 (RPMI-1640) with L-glutamine (Thermo Fisher Scientific, Inc., Warsaw, Poland), supplemented with $10 \%$ fetal bovine serum (FBS; Thermo Fisher Scientific, Inc. Warsaw, Poland), and antibiotics (penicillin-streptomycin $50 \mathrm{IU} / \mathrm{ml}$ and 50 $\mu \mathrm{g} / \mathrm{ml}$, Life Technologies, Warsaw, Poland). Strainers were rinsed twice with media to remove remaining cells. Then, cells were centrifuged (500 $\mathrm{x} \mathrm{g}, 5 \mathrm{~min}$, room temperature), the resulting pellet resuspended in media and cells counted in a hematological analyzer (Exigo veterinary hematological system; Boule Medical AB, Stockholm, Sweden). A cell suspension of $1 \times 10^{6}$ cells $/ \mathrm{ml}$ was used to evaluate the phenotyping and response to mitogens. Splenocyte viability was determined using the trypan blue exclusion test and amounted to $>95 \%$ cell viability.

\section{Phenotypic determination of splenocytes}

Spleen cells suspensions $\left(100 \mu 1,1 \times 10^{6}\right.$ cell $\left./ \mathrm{ml}\right)$ were washed twice with PBS and centrifuged (500 $\mathrm{x} \mathrm{g}, 5 \mathrm{~min}$, room temperature). Cell pellet was resuspended in $1 \mathrm{ml}$ of PBS and labeled by surface staining with the following fluorochrome-coniugated anti-mouse antibodies against a number of cell surface markers: Mouse T lymphocyte Subset Antibody Cocktail with Isotype Control [monoclonal: hamster anti-mouse phycoerythrin (PE)-Cyanine 7 cluster of differentiation (CD) rat anti-mouse 3e, PE CD4 and rat anti-mouse allophycocyanin (APC) CD8a; cat. no 558431], Mouse B Lymphocyte Activation Antibody Cocktail with Isotype Control (monoclonal: rat anti-mouse PE-Cy7 CD25, hamster anti-mouse PE CD69 and rat anti-mouse APC CD19; BD Bioscences; cat. No. 558063) and PE rat anti-mouse CD335 (natural killer cell p46-related protein; BD Biosciences; cat. No. 560757), according to the manufacturer's instructions ( $20 \mathrm{~min}$. of incubation, room temperature). Red blood cells from spleens blood vessels were lysed (10 min, Lysing Solution cat. no. 349202; BD Biosciences). Phenotypic analysis was then performed using flow cytometry (FACSCalibur; BD Biosciences). Results of this analysis are presented as the mean $\%$ of splenocytes \pm standard error of the mean. 


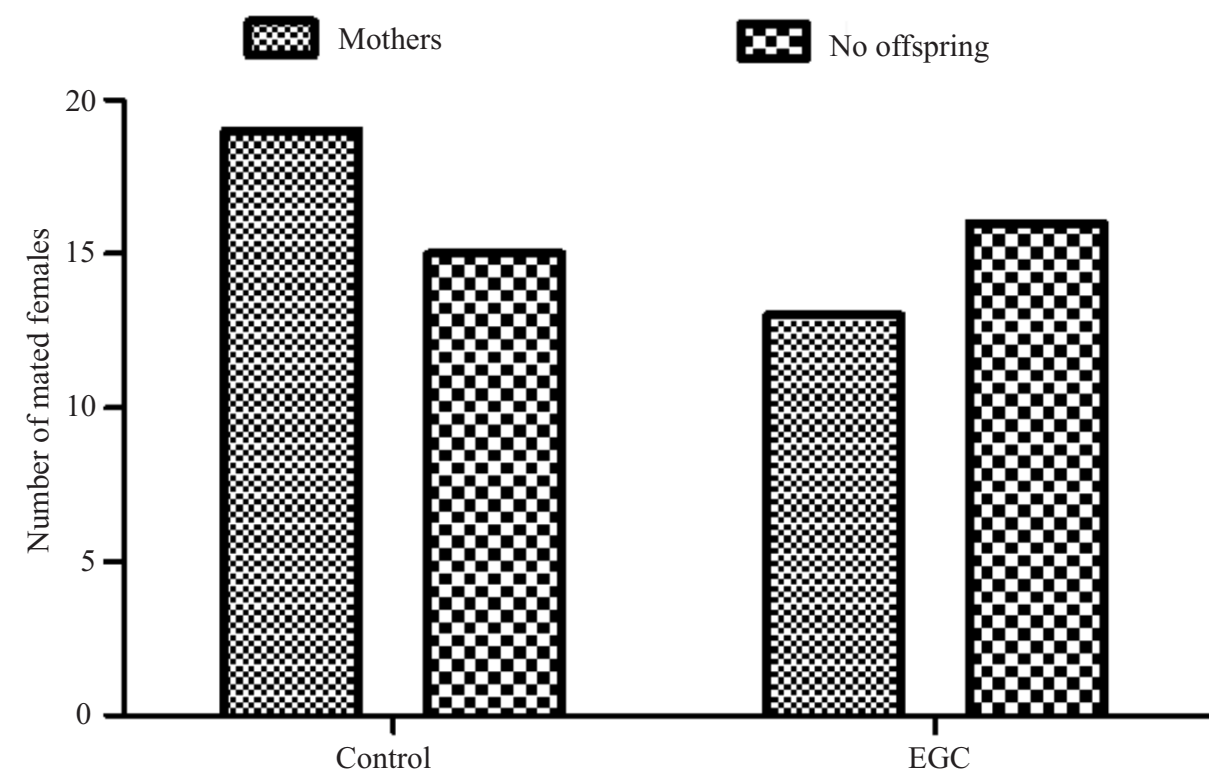

Fig. 1. Results of mated females supplemented during pregnancy and nursing with EGC $0.2 \mathrm{mg} / \mathrm{kg}$ b.m. Mice with a copulatory plug were considered "mated females". Fisher's exact test, p value 0.4527 ; alpha $>0.05$; ns.

Table 1. Mean body weight, spleen mass and relative spleen mass of control offspring and progeny of mice fed epigallocatechin (EGC) during pregnancy and lactation. $\mathrm{p}$ - statistical level in comparison to the control group; $\mathrm{n}$ - number of animals. Unpaired t test.

\begin{tabular}{lccccccc}
\hline & \multicolumn{2}{c}{ Mouse $(\mathrm{g})$} & \multicolumn{2}{c}{ Spleen $(\mathrm{mg})$} & \multicolumn{3}{c}{ Relative Spleen mass (mg/g) } \\
\cline { 2 - 8 } & Control & EGC & Control & EGC & Control & EGC \\
\hline Mean & 18.17 & 16.92 & 84.0 & 80 & 4.66 & 4.76 \\
\hline $\mathrm{n}$ & 90 & 34 & 90 & 34 & 30 & 34 & 0.18 \\
\hline $\mathrm{pEM}$ & 0.25 & 0.42 & 1.1 & 3.1 & & & $\mathrm{~ns}$ \\
\hline
\end{tabular}

\section{Response of splenocytes to mitogens}

Response to mitogens was measured using the alamarBlue assay. Splenocytes were seeded into 96-well plates $\left(100 \mu \mathrm{l}\right.$ of $1 \times 10^{5}$ cells in one well), incubated for $1 \mathrm{~h}$ in standard condition $\left(5 \% \mathrm{CO}_{2}, 95 \%\right.$ humidity, $37^{\circ} \mathrm{C}$ ) and then the one of mitogens was added: Lipopolysaccharide (LPS; $20 \mu \mathrm{g} / \mathrm{ml}$ ), Concanavalin A (ConA; $5 \mu \mathrm{g} / \mathrm{ml})$ or phytohaemagglutinin (PHA; $2 \mu \mathrm{g} / \mathrm{ml}$ ) (all purchased from Sigma-Aldrich, Poznan, Poland) in RPMI-1640 to the final volume of $200 \mu$ l. Following $24 \mathrm{~h}$ of incubation, alamarBlue (1:10, v/v, Thermo Fisher Scientific, Inc.) was added to the wells. Cells were incubated for further $48 \mathrm{~h}$ at standard conditions $\left(37^{\circ} \mathrm{C}, 5 \% \mathrm{CO}_{2}\right.$, $95 \%$ relative humidity). AlamarBlue fluorescence (excitation $544 \mathrm{~nm}$, emission $590 \mathrm{~nm}$ ) of the wells was measured using a FLUOstar Omega Microplate Reader (BMG Labtech GmbH, Ortenberg, Germany).

\section{Anti-sheep red blood cell (SRBC) CD2 antibody production}

Progeny mice (6-weeks old) were immunized with $5 \%$ SRBC $0.2 \mathrm{ml}$ intraperitoneal injection, (GrasoBiotech, Starogard Gdanski, Poland) 7 days prior to being bled from the retro-orbital plexus under anesthesia. Anti-SRBC antibody levels were evaluated by performing the hemagglutination assay on a series of dilutions of sera, as previously described (Lewicki et al. 2016). Briefly, after inactivation $\left(56^{\circ} \mathrm{C}, 30 \mathrm{~min}\right)$, $1 \%$ of SRBC was added to and the mixture was incubated for $60 \mathrm{~min}$ at $37^{\circ} \mathrm{C}$, followed by a further $18 \mathrm{~h}$ at $4^{\circ} \mathrm{C}$, centrifuged $\left(10 \mathrm{~min}, 150 \mathrm{x} \mathrm{g}, 4^{\circ} \mathrm{C}\right)$ and shaken. The hemagglutination titer was evaluated using light microscopy as the highest dilution in which $\geq 3$ cell conglomerates were present in $\geq 3$ consecutive fields at an objective magnification of $\mathrm{x} 20$. For the purposes of statistical analysis, the results were transformed into logarithm inversions of the titers. 

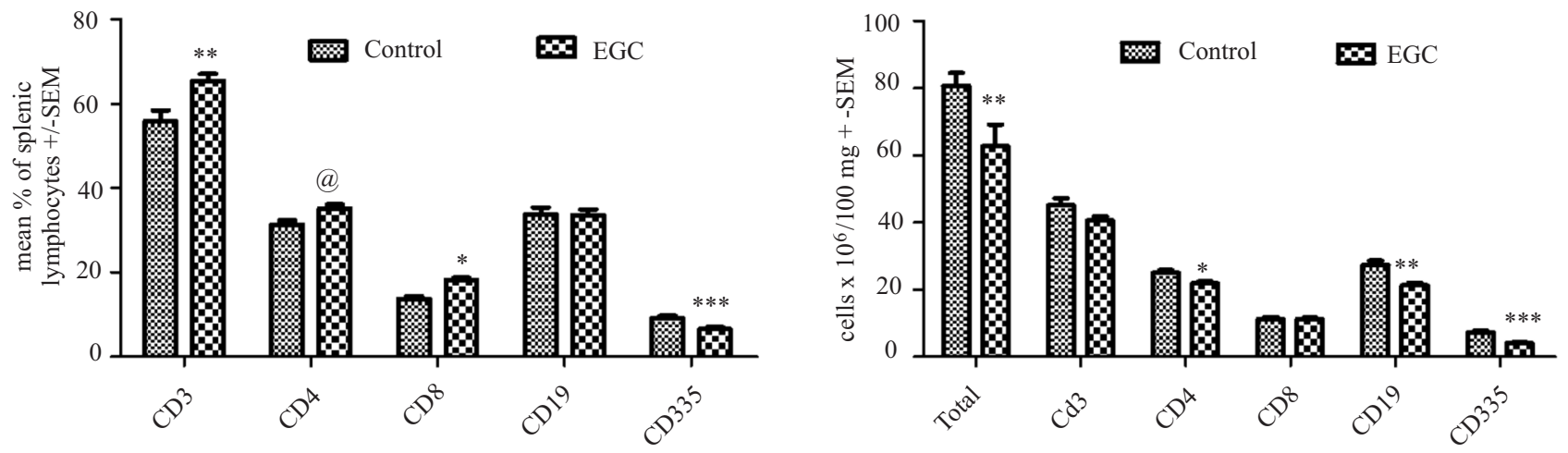

Fig. 2. Phenotype of spleen cells isolated from progeny of mothers fed during pregnancy and lactation epigallocatechin (EGC) or placebo (control). A - cells percentages (mice: control $n=15$; EGC $n=6$ ), B - cell numbers (mice: control $n=42$; $E G C ~ n=19)$. $*, * * * * *-$ level of statistical significance, respectively: $\mathrm{p}<0.05, \mathrm{p}<0.01$ and $\mathrm{p}<0.001, @-0.1>\mathrm{p}>0.05$. Analysis: unpaired $\mathrm{t}$ test and Two-way ANOVA.

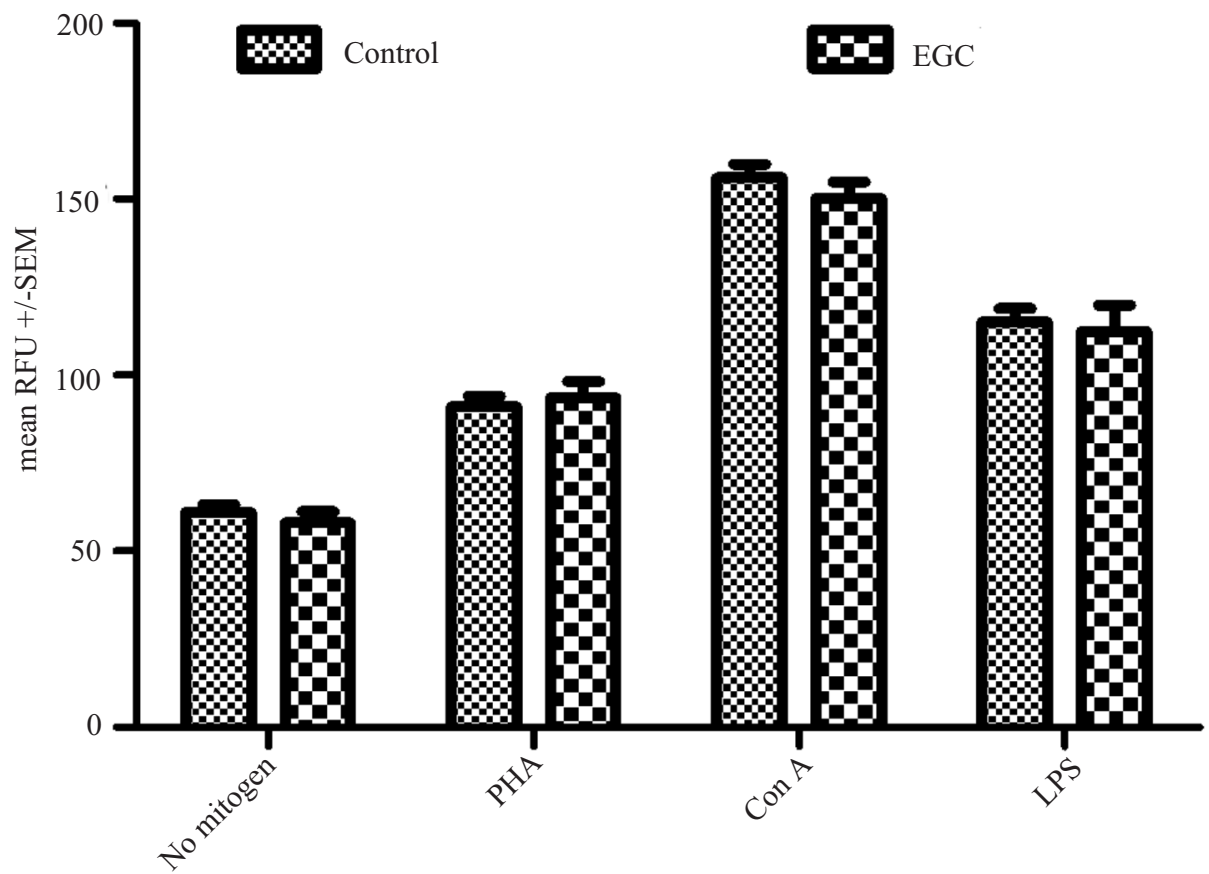

Fig. 3. Splenic lymphocytes proliferation results following phytohemagglutinin (PHA) Concanavalin A (ConA) or lipopolysaccharide (LPS) stimulation. Spleens were isolated from progeny of mothers fed during pregnancy and lactation epigallocatechin (EGC) or placebo (control). Mice: control $n=31$; $E G C n=15$. Results are presented as the mean RFU (relative fluorescence units) \pm SEM. Two-way ANOVA and unpaired t test; $\mathrm{p}$ (treatment) $=0.4716$, n.s.

\section{Statistical analysis of data}

Shapiro-Wilk normality test, 2-way ANOVA, Fisher exact and unpaired tests were used (GraphPadPrism, Saint Diego, USA). The results are presented as mean \pm SEM,

\section{Results}

Supplementation of mice with EGC slightly increased the number of mated females without offspring, however, the difference from the controls was not significant (Fig. 1). The ratio of mothers to the mated females without offspring was 19/15 in the control and 13/16 in EGC group. No difference in litter size was observed $(4.78 \pm 0.35, \mathrm{n}=19$ and $4.62 \pm 0.31$, $\mathrm{n}=13$ ) in the control and EGC group, respectively.

Offspring were weighed 6 weeks after birth. Mean weight of the control mice was $18.17 \mathrm{~g}$. The mice born from mothers fed epigallocatechin during pregnancy and lactation were significantly lighter in comparison to the controls. No differences in spleen mass and relative spleen mass index were observed between the offspring of the control mice and EGC progeny (Table 1). 
Table 2. Morphometric evaluation of spleens isolated from progeny of mothers fed during pregnancy and lactation epigallocatechin (EGC, $\mathrm{n}=10$ ) or placebo (control, $\mathrm{n}=10)$. $\mathrm{p}$ - statistical level in comparison the to control group (unpaired $\mathrm{t}$ test).

\begin{tabular}{lcccc}
\hline Groups & $\begin{array}{c}\text { Number of analyzed } \\
\text { images }\end{array}$ & $\begin{array}{c}\text { Number of lymphatic } \\
\text { nodules /field } \\
\text { mean } \pm \text { SE }\end{array}$ & $\begin{array}{c}\text { Number of analyzed } \\
\text { lymphatic nodules }\end{array}$ & $\begin{array}{c}\text { Mean diameter } \\
\text { of lymphatic nodule } \\
(\mu \mathrm{m}) \pm \text { SEM }\end{array}$ \\
\hline Control & 34 & $9.23 \pm 0.49$ & 316 & $323 \pm 7$ \\
\hline Epigallocatechin & 34 & $5.79 \pm 0.43$ & 199 & $361 \pm 10$ \\
\hline $\mathrm{p}$ & - & $\mathrm{p}<0.01$ & - & $\mathrm{p}<0.001$ \\
\hline
\end{tabular}

The results of cytometric analysis and cellularity of spleens are presented in Fig. 2 as the \% of cell populations with various $\mathrm{CD}$ markers and as the number of cells per $100 \mathrm{mg}$ of the splenic tissue. Cellularity of spleens was significantly lower in EGC offspring than in the controls. Cytometric analysis showed that this decline concerns lymphocytes with CD335 $(\mathrm{p}<0.001)$, CD19 $(\mathrm{p}<0.01)$ and CD4 $(\mathrm{p}<0.05)$ markers.

No differences were found in the proliferative response of splenic cells to mitogens between mice born to EGC and born to control mothers (Fig. 3).

Morphometry of EGC offspring spleens revealed a lower number of lymphatic nodules and their larger diameter than those observed in the control offspring (Table 2).

No difference was found in the humoral response to the immunization with SRBC between two examined groups of progeny mice (mean log titer was 3.66 $\pm 0.23 n=9$ and $4.08 \pm 0.22 n=12$ for the controls and EGC pups, respectively).

No macroscopic abnormalities were observed in the anatomy of spleens in neither the experimental EGC nor in the control group. Microscopically, in the controls, splenic lymphatic nodules with well-developed germinal centers were present. In the experimental EGC group enlarged white pulp was seen. Germinal centers were surrounded with mantle zone and pale staining marginal zone. The lymphatic nodules in EGC spleens were less frequent and larger in comparison with those in the control animals. Morphometry of EGC offspring spleens revealed a lower number of lymphatic nodules and their larger diameter than those observed in the control offspring (Table 2).

\section{Discussion}

Our previous studies showed that some commonly consumed nutritional ingredients might affect embryonic and postnatal development when administered regularly to pregnant and afterwards nursing mice. Such treatment may affect and change both cellular and humoral immune response of the progeny (Chorostowska-Wynimko et al. 2004, Skopińska-Różewska et al. 2004) The results of these studies have suggested that adverse effects can be dependent on the action of catechins (Skopiński et al. 2003, Wasiutyński et al. 2005).

The present study showed that giving pregnant mice epigallocatechin affects their offspring. Firstly, there was a reversal of proportion of females with children to females without children, although Fisher's exact test did not confirm the statistical significance of this phenomenon. We have observed similar (but statistically significant) results in our previous research on the model of the pregnant mice, in which we obtained a similar reversal of this relationship (to the disadvantage of mothers) in mice fed extracts of Rhodiola kirilowii containing substantial amount of catechins (Zdanowski et al. 2014). The daily dose of EGC (4 micrograms) that was used in the present investigations corresponds to the total of catechins (catechin, epicatechin, epigallocatechin) present in 400 micrograms of hydro-alcoholic $R$. kirilowii extract. This is a much lower dose than that used in our previous experiments in which we studied chocolate and cocoa catechins on the same experimental model of pregnant mice. In that research mice were fed $400 \mathrm{mg} /$ day bitter chocolate or, estimated by HPLC comparable amount $352 \mu \mathrm{g}$ mixture of main cocoa catechins (catechin, epicatechin, epigallocatechin). In that experiments we found negative correlation between angiogenic activity of embryo tissue homogenates and their EGC concentration (Skopiński et al. 2003, 2004, Skopińska-Różewska et al. 2003, 2004, Wasiutyński et al. 2005). Therefore, we can assume that if one was to increase both the number of tests as well as the dose of EGC the phenomenon would become statistically significant.

Extracts of $R$. kirilowii beyond the catechins also contained other anti-angiogenic compounds including salidroside. The question is whether anti-angiogenic activity could be the cause of this phenomenon, or whether it was related to other mechanisms, which were described by authors dealing with the influence of polyphenols on the early stages of embryo develop- 
ment (Yoshida et al. 2013). It was reported that tea epigallocatechin-3-gallate increases 8-isoprostane level and induces caudal regression developing rat embryos (Wang et al. 2007). Epicatechin gallate also decreases the viability and subsequent embryonic development of mouse blastocysts (Tu et al. 2010). Epigallocatechin gallate induces embryonic toxicity in mouse blastocysts through apoptosis (Fan and Chan 2014). Antiangiogenic activity could have had an impact on the further stages of individual development in the prenatal and postnatal periods. We have not found any difference in the number of offspring per litter, but we have found significant differences in body weight of six-week adult offspring to the disadvantage of EGC progeny. We have also observed highly significant differences in the number of splenocytes in $100 \mathrm{mg}$ of spleen tissue (which we named "cellularity"), manifested by a decrease in the total number of leukocytes (without any difference in proportion of monocytes, lymphocytes and granulocytes), a highly significant decrease in both the percentage and total number of natural killer lymphocyte cells. This is harmful because natural killer (NK) cells contribute to a variety of innate immune responses to pathogens and tumors. We also found a reduced total number of CD19 (B) and CD4 (T) lymphocytes, that is also worrying. The number of cytotoxic-suppressive CD8 lymphocytes has remained the same, while the percentage has increased. These changes are accompanied by morphometric changes in the spleen showing a reduced number as well as larger diameter of lymphatic nodules in the offspring of mothers receiving EGC. This begs a question why such changes have not been previously observed in the offspring of mothers treated with extracts of Rhodiola. One explanation may be that these extracts also contain high doses of other polyphenols, including quercetin, that show the reverse action on cellularity with respect to the catechins (as demonstrated in the work of Lewicki et al. 2015). They can also act protectively by partially eliminating adverse effects of catechins. In the present study, we found no functional disturbances in a range of parameters (proliferative response of splenocytes to various mitogens, antibody production). However, one cannot rule out that such disturbances will not manifest themselves in the later years of life of mice offspring of mothers fed with EGC.

\section{Conclusions}

Feeding of mice-mothers EGC had negative influence on spleen cellularity and architecture in their progeny. However, EGC did not significantly influence the humoral (after immunization with SRBC) and cellular (proliferation of splenocytes after stimulation with mitogens) immunological response. Therefore, in our opinion, EGC feeding of mothers is relatively safe for the functioning of immune system in their progeny.

\section{Acknowledgments}

The study was supported by National Centre of Science, grant number: 2012/05/B/NZ 7/03219.

\section{References}

Bałan BJ, Skopinska-Różewska E, Barcz E, Sokolnicka I, Gawrychowski K, Strzelecka H (1999) The effect of selected phenolic acids on angiogenic activity of ovarian cancer cells - preliminary report. Onkol Pol 2: 203-208.

Bałan BJ, Lewicki S, Siwicki AK, Stelmasiak M, Skopiński P, Skopińska-Różewska E，Wasiutyński A，Zdanowski $\mathrm{R}$ (2017) Morphometric abnormalities in spleen and kidney of the progeny of mice fed American cranberry extract (Vaccinium macrocarpon) during pregnancy and lactation. Pol J Vet Sci 20: 57-65.

Cao Y, Cao R, Brakenhielm E (2002) Antiangiogenic mechanisms of diet-derived polyphenols. J Nutr Biochem 13: 380-390.

Cesta MF (2006) Normal structure, function and histology of the spleen. Toxicol Pathol 34: 455-465.

Chorostowska-Wynimko J, Skopińska-Różewska E, Sommer E, Rogala E, Skopiński P, Wojtasik E (2004) Multiple effects of theobromine on fetus development and postnatal status of the immune system. Int $\mathbf{J}$ Tissue React 26: 53-60.

Fan YC, Chan WH (2014) Epigallocatechin gallate induces embryonic toxicity in mouse blastocysts through apoptosis. Drug Chem Toxicol 37: 247-254.

Fotsis T, Pepper MS, Aktas E, Breit S, Rasku S, Adlercreutz H, Wahala K, Montesano R, Schweigerer L (1997) Flavonoids, dietary- derived inhibitors of cell proliferation and in vitro angiogenesis. Cancer Res 57: 2916-2921.

Grosso G, Stepaniak U, Topor-M dry R, Szafraniec K, Paj k A (2014) Estimated dietary intake and major food sources of polyphenols in the Polish arm of the HAPIEE study. Nutrition 30: 1398-1403.

Kandaswami C, Lee LT, Lee PP, Hwang JJ, Ke FC, Huang YT, Lee MT (2005) The antitumor activities of flavonoids. In Vivo 19: 895-909.

Kim MH (2003) Flavonoids inhibit VEGF/bFGF-induced angiogenesis in vitro by inhibiting the matrix-degrading proteases. J Cell Biochem 89: 529-538.

Kim KK, Singh AP, Singh RK, Demartino A, Brard L, Vorsa N, Lange TS, Moore RG (2012) Anti-angiogenic activity of cranberry proanthocyanidins and cytotoxic properties in ovarian cancer cells. Int J Oncol 40: 227-235.

Lewicki S, Stankiewicz W, Skopińska-Różewska E, Wilczak J, Leśniak M, Suska M, Siwicki AK, Skopinski P, Zdanowski R (2015) Spleen content of selected polyphenols, splenocytes morphology and function in mice fed Rhodiola kirilowii extracts during pregnancy and lactation. Pol J Vet Sci 18: 847-855. 
Lewicki S, Bałan BJ, Skopińska-Różewska E, Zdanowski R, Stelmasiak M, Szymański Ł, Stankiewicz W (2016) Modulatory effects of feeding pregnant and lactating mice Rhodiola kirilowii extracts on the immune system of offspring. Exp Ther Med 12: 3450-3458.

Lewicki S, Skopińska-Różewska E, Bałan BJ, Kalicki B, Patera J, Wilczak J, Wasiutyński A, Zdanowski R (2017) Morphofunctional renal alterations in progeny of mice fed Rhodiola kirilowii extracts or epigallocatechin during pregnancy and lactation. J Med Food 20: 86-92.

Patera J, Chorostowska-Wynimko J, Słodkowska J, Borowska A, Skopiński P, Sommer E, Wasiutyński A, Skopińska-Różewska E (2006) Morphometric and functional abnormalities of kidneys in the progeny of mice fed chocolate during pregnancy and lactation. Folia Histochem Cytobiol 44: 207-211.

Shi J, Liu F, Zhang W, Liu X, Lin B, Tang X (2015) Epigallocatechin-3-gallate inhibits nicotine-induced migration and invasion by the suppression of angiogenesis and epithelial mesenchymal transition in non-small cell lung cancer cells. Oncol Rep 33: 2972-2980.

Skopińska-Różewska E, Mościcka-Wesołowska M, Wasiutyński A, Małdyk J, Malejczyk M, Pazdur J (1985) Lymphatic system of mice born from mothers treated with ampicillin or cloxacillin during gestation. Arch Immunol Ther Exp (Warszawa) 34: 203-208.

Skopińska-Różewska E, Bałan BJ, Sommer E, Chorostowska-Wynimko J, Bany J, Wasiutyński A, Siwicki AK (2004 a) The influence of chocolate feeding of pregnant mice on the immunological response of their progeny. Pol J Food Nutr Sci 13: 67-70.

Skopińska-Różewska E, Chorostowska-Wynimko J, Rogala E, Radomska-Leśniewska D, Skopiński P, Sommer E, Siwicki AK (2004 b) Caffeic acid feeding of pregnant and lactating mice influences the immune response of their progeny. Pol J Food Nutr Sci 13: 63-66.

Skopiński P, Skopińska-Różewska E, Sommer E, Chorostowska-Wynimko J, Rogala E, Cendrowska I, Chrystowska D, Filewska M, Biaas-Chromiec B, Bany J (2003) Chocolate feeding of pregnant mice influences length of limbs of their progeny. Pol J Vet Sci 6 (Suppl 3): 57-59.

Skopiński P, Skopińska-Różewska E, Kamiński A, Dziedzic-Gocławska A, Sommer E, Chorostowska-Wynimko J, Cendrowska I, Chrystowska D, Sadło J, Siwicki AK
(2004) Chocolate feeding of pregnant mice resulted in epigallocatechin related embryonic angiogenesis suppression and bone mineralization disorder. Pol J Vet Sci 7: 131-133.

Skopinski P, Zdanowski R, Ba an BJ, Siwicki AK, Kocik J, Lewicki S, Suska M, Pastewka K, Skopińska-Różewska E, Demkow U (2013) Aloe arborescens and American cranberry (Vaccinium macrocarpon) extracts inhibit tumor-induced cutaneous angiogenesis in mice. Cent Eur J Immunol 38: 480-485.

Tu HC, Chen CP, Chan WH (2010) Epicatechin gallate decreases the viability and subsequent embryonic development of mouse blastocysts. Taiwan J Obstet Gynecol 49: 174-180.

Wang CC, Chu KO, Chong WS, Li WY, Pang CP, Shum AS, Lau TK, Rogers MS (2007) Tea epigallocatechin-3- gallate increases 8-isoprostane level and induces caudal regression in developing of rat embryos. Free Radic Biol Med 43: 519-527.

Wasiutyński A, Siwicki AK, Bałan BJ, Sommer E, Bany J, Wąsik M, Patnicki A, Skurzak H, Skopińska-Różewska E (2005) Inhibitory effect of cocoa catechins on embryonic and tumor angiogenesis in mice. Pol J Environ Studies 14(II): 800-805.

Walzer T, Bléry M, Chaix J, Fuseri N, Chasson L, Robbins SH, Jaeger S, André P, Gauthier L, Daniel L, Chemin K, Morel Y, Dalod M, Imbert J, Pierres M, Moretta A, Romagné F, Vivier E (2007) Identification, activation, and selective in vivo ablation of mouse NK cells via NKp46. Proc Natl Acad Sci USA 104: 3384-3389.

Yoshida N, Kuriyama I, Mizushina Y (2013) Inhibitory effects of catechin derivatives on mammalian DNA polymerase and topoisomerase activities and mouse one-cell zygote development. J Biosci Bioeng 115: 303-309.

Zdanowski R, Skopińska-Różewska E, Wasiutyński A, Skopiński P, Siwicki AK, Sobiczewska E, Lewicki S, Buchwald W, Kocik J, Stankiewicz W (2012) The effect of Rhodiola kirilowii extracts on tumor-induced angiogenesis in mice. Cent Eur J Immunol 37: 131-139.

Zdanowski R, Lewicki S, Sikorska K, Żmigrodzka M, Buchwald W, Wilczak J, Skopińska-Różewska E (2014) The influence of aqueous and hydro-alcoholic extracts of roots and rhizomes of Rhodiola kirilowii on the course of pregnancy in mice. Cent Eur J Immunol 39: 471-475. 